\title{
MENYUSUN INSTRUMEN PENILAIAN UNTUK PEMBELAJARAN EKOLOGI BERORIENTASI LITERASI SAINTIFIK
}

\author{
Adib Rifqi Setiawan ${ }^{1}$ \\ ${ }^{1}$ Pondok Pesantren Ath-Thullab \\ Kajeksan, RT 002, RW.002, Kajeksan, Kudus, 59315, Indonesia \\ E-mail: alobatnic@gmail.com
}

\begin{abstract}
The goal of this cross-sectional survey work was to find the validity and reliability of assessment instrument for ecological learning scientific literacy oriented's. To reveal validity is assessed based on obtain judgement expert and reliability measured by internal consistency. It was gained that the validity is 7 items very feasible and 3 item quite feasible with reliability's value is 0.763 . It shows that all items can be used to analyzing difficulties of students for designing ecological learning scientific literacy oriented's lesson plan.

Keywords: assessment, ecological learning, scientific literacy

Abstrak: Tujuan dari riset tipe cross-sectional survey ini ialah untuk menemukan keabsahan dan keandalan instrumen penilaian untuk pembelajaran ekologi berorientasi literasi saintifik. Keabsahan diungkap berdasarkan penilaian pakar dan keandalan diukur menggunakan konsistensi internal. Diperoleh bahwa keabsahan 7 butir soal memenuhi kriteria sangat layak dan 3 butir soal memenuhi kriteria cukup layak dengan nilai keandalan sebesar 0.763 . Ini menunjukkan bahwa semua butir soal dapat dipakai untuk menganalisis kesulitan siswa sebagai bahan merancang rencana pembelajaran ekologi berorientasi literasi saintifik.
\end{abstract}

Kata kunci: instrumen penilaian, literasi saintifik, pembelajaran ekologi

Setiawan \& Sari (2019) mengulas kurikulum nasional Indonesia yang hasilnya menunjukkan bahwa telah mengalami perubahan sebanyak 10 kali, yakni pada 1947, 1952, 1964, 1968, 1975, 1984, 1994, 2004, 2006, serta 2013. Perubahan tersebut wajar dilakukan karena keadaan masyarakat beserta tantangan yang dihadapi juga berubah. Tujuan dari semua perubahan yang dilakukan ialah untuk meningkatkan kualitas pendidikan Indonesia, termasuk dari pembelajaran Ilmu Pengetahuan Alam (IPA). Namun, ulasan riset menyampaikan dan fakta lapangan menunjukkan bahwa selama ini belum tampak hasil (outcomes) menggembirakan berkelanjutan yang diperoleh dari pembelajaran di Indonesia.
Setiawan (2019a), misalnya, mengungkap bahwa terdapat fenomena unik dalam pembelajaran sains di Indonesia. Ungkapan ini didasari oleh perbandingan antara prestasi siswa Indonesia dalam ajang olimpiade internasional pada 2018 dengan penilaian literasi saintifik dari PISA (Programme for International Student Assessment) pada 2015 (Setiawan, 2019a: 7). Perluasan data menunjukkan bahwa ungkapan tersebut tak dapat begitu saja disangkal, karena siswa Indonesia memang memiliki prestasi bagus dalam ajang International Science Olympiads (ISOs) sejak kali pertama ikut serta, baik untuk fisika, biologi, astronomi dan astrofisika, geologi, serta kimia (IPhO, 2019; IBO, 2019; IOAA, 2019; IChO, 2019; IESO, 2019). Sayangnya, secara bersamaan raihan ISOs tersebut disertai 
keberadaan yang konsisten di papan bawah dalam empat periode terakhir penilaian literasi saintifik dari PISA (OECD, 2019). Lebih lanjut, diungkapkan bahwa selayaknya raihan olimpiade diperlakukan sebagai hiburan semata, bukan gambaran keberhasilan pendidikan sains karena peserta merupakan siswa pilihan (Setiawan, 2019: 7-8).

Fenomena unik yang diungkap oleh Setiawan (2019a) dilanjut dengan penyampaian saran agar fokus yang serius harus diarahkan kepada hasil PISA. Hal ini karena kerangka kerja yang digunakan sebagai dasar untuk pengukuran dapat diadopsi atau setidaknya diadaptasi ke dalam pembelajaran (Setiawan, 2019a: 8). Saran tersebut selaras dengan Utari, dkk. (2017) yang mengungkap bahwa strategi pembelajaran harus ditentukan dibangun dengan baik untuk melatih literasi saintifik, termasuk menjelaskan fenomena alam, membangun dan mengevaluasi percobaan, serta menafsirkan data yang diperoleh dari bukti ilmiah. Ungkapan tersebut disampaikan berdasarkan ulasan deskriptif menggunakan dimensi Marzano terhadap pelaksanaan desain pembelajaran termodinamika untuk melatih literasi saintifik (Utari, dkk., 2017: 3-4). Dari sisi lain, Rustaman (2017) menyampaikan bahwa pembelajaran sains selayaknya menjadi sarana untuk melatih keterampilan saintifik serta menumbuhkan kepedulian terhadap alam dan upaya pelestarian fungsinya. Keseluruhan informasi tersebut menguatkan anggapan bahwa hasil PISA perlu ditindaklanjuti secara serius dalam bentuk mengarahkan pembelajaran sains untuk melatih literasi saintifik.

Literasi saintifik telah dijelaskan oleh Hurd (1998) sebagai kompetensi yang diperlukan oleh warga negara untuk berpikir rasional tentang sains dalam kaitannya dengan masalah pribadi, sosial, politik, ekonomi, dan masalah yang mungkin ditemui seseorang sepanjang hidup. Konsep literasi saintifik harus mengenali berbagai kekuatan yang berubah dalam masyarakat, termasuk kemunculan era informasi, kelahiran ekonomi global, dan dunia daring (Hurd, 1998: 410). Kerangka kerja PISA dari OECD (2018) mendefinisikan literasi saintifik sebagai kemampuan untuk terlibat masalah yang berhubungan dengan sains dan dengan ide sains sebagai warga negara yang reflektif. Karena itu, orang yang memiliki literasi saintifik bersedia untuk terlibat komunikasi ilmiah tentang sains dan teknologi yang membutuhkan kompetensi untuk: menjelaskan fenomena secara ilmiah, mengevaluasi dan merancang penyelidikan ilmiah, juga menafsirkan data dan bukti secara ilmiah (OECD, 2018: 75).

Berdasarkan uraian tersebut, riset ini bertujuan untuk menemukan keabsahan dan keandalan rancangan instrumen penilaian pembelajaran ekologi beroerientasi literasi saintifik. Rancangan soal disusun berdasarkan indikator domain kompetensi literasi saintifik dari kerangka kerja PISA (OECD, 2018: 75). Indikator tersebut dikaitkan dengan topik ekologi atas dasar pertimbangan agar dapat digunakan dalam pembelajaran di sekolah menengah. Karena itu, rumusan masalah yang menjadi fokus riset ini ialah, "Bagaimana keabsahan dan keandalan rancangan instrumen penilaian pembelajaran ekologi beroerientasi literasi saintifik?"

\section{METODE}

Tujuan dari riset ini adalah untuk menemukan keabsahan dan keandalan rancangan instrumen penilaian pembelajaran ekologi beroerientasi literasi saintifik. Karena itu dibutuhkan data berupa lembar validasi dan nilai keabsahan instrumen. Berdasarkan tujuan riset dan kebutuhan data, metode riset yang dapat dipakai ialah tipe crosssectional survey. Tipe ini berupaya untuk memperoleh informasi yang dikumpulkan pada titik waktu yang kira-kira sama (Fraenkel \& Wallen, 2009: 391). 
Sampel diambil dengan teknik penyampelan bertujuan (purposive sampling) terhadap 4 pakar dan 122 siswa tingkat sekolah menengah di Kabupaten Kudus. Teknik ini dipilih karena tujuan spesifik riset memerlukan sampel yang memenuhi kriteria (Fraenkel \& Wallen, 2009: 99). Kriteria untuk 4 pakar tersebut berupa akademisi dengan bidang kepakaran literasi saintifik (1 orang, selanjutnya Pakar-1) dan evaluasi pembelajaran biologi (1 orang, selanjutnya Pakar-2) serta praktisi pembelajaran biologi sekolah menengah (1 orang, selanjutnya Pakar-3) dan praktisi profesional bidang bahasa (1 orang, selanjutnya Pakar-4). Sementara untuk siswa kriteria yang dipakai ialah merupakan siswa aktif di sekolah menengah yang mengambil program peminatan Ilmu Alam.

Instrumen yang dipakai untuk mengukur keabsahan ialah lembar validasi butir pernyataan. Lembar tersebut diberi skor menggunakan skala Likert. Kelebihan skala Likert sebagai pengukur tanggapan secara verbal maupun numerik terhadap kuesioner, dapat memberi nilai kuantitatif dalam rentang spektrum yang panjang (Likert, 1932: 7). Sedangkan kekurangannya berupa sikap terdistribusi secara normal ke dalam lima kategori persetujuan (Likert, 1932: 42). Memperhatikan kelebihan dan kekurangan, skala Likert dipilih karena hasilnya dapat diolah baik secara statistik maupun desktriptif. Letak kekurangan berupa pembagian tingkat persetujuan ke dalam lima kategori diatasi dengan menggunakan tujuh tingkat secara numerik (Dawes, 2008: 61).

Nilai keabsahan (validity) ditentukan berdasarkan penilaian pakar, masingmasing terhadap ketepatan antara rancangan dan indikator, pertanyaan dan jawaban, serta soal dengan subjek sasaran (Fraenkel \& Wallen, 2009: 148). Hasil validasi berupa penilaian numerik skala 7 terhadap setiap butir pernyataan yang diolah menggunakan persamaan 1 (Setiawan, 2019b: 227):

$$
P(s)=\frac{s}{N} \times 100 \%
$$

keterangan:

$$
\begin{array}{ll}
P(s) & =\text { Nilai setiap butir pernyataan } \\
S & =\text { skor setiap butir pernyataan } \\
N & =\text { jumlah butir pernyataan }
\end{array}
$$

kemudian ditafsirkan berdasarkan tabel 1 . Berdasarkan tabel 1 tersebut, instrumen dapat digunakan kalau memenuhi kriteria 'sangat layak' atau 'cukup layak' (Setiawan, 2019b: 227).

Sementara untuk mengukur keandalan (reliability), dipakai kuesioner yang telah diperbaiki berdasarkan lembar validasi butir pernyataan. Keandalan instrumen ditentukan berdasarkan konsistensi internal (internal consistency). Konsistensi internal biasanya diukur dengan alfa Cronbach $(\alpha)$, salah satu cara statistik untuk mengetahui korelasi berpasangan antar butir pertanyaan atau pernyataan, yang dapat dihitung menggunakan persamaan KuderRichardson Approaches (KR20) (persamaan 2) (Cronbach, 1951: 299):

$$
\alpha=\frac{n}{n-1}\left(1-\frac{\sum_{i} V_{i}}{V_{t}}\right)
$$

keterangan:

$\alpha \quad=$ koefisien alfa

$n \quad=$ jumlah butir pernyataan

$V i \quad=$ simpangan baku setiap butir

$V t \quad=$ simpangan baku semua

Persamaan 2 mengungkap bahwa alfa Cronbach adalah fungsi dari jumlah butir pernyataan serta simpangan baku setiap butir dan keseluruhan. Ini menunjukkkan bahwa nilai alfa Cronbach dapat meningkat ketika interelasi antar butir meningkat, sehingga dapat dipakai untuk memperkirakan konsistensi internal dari keandalan skor instrumen. Persamaan 2 juga bermakna bahwa dibutuhkan uji coba yang hasilnya dapat ditafsirkan berdasarkan tabel 2. Berdasarkan tabel 2 tersebut, instrumen dapat dipakai setelah satu kali uji coba kalau nilai koefisien alfa lebih besar dari 0,70 (Fraenkel \& Wallen, 2009: 157-8) 
.Tabel 1. Penafsiran Penilaian Keabsahan Instrumen

\begin{tabular}{lcl}
\hline No. & Rentang Rerata Penilaian Numerik Pakar $(\%)$ & Kriteria Kelayakan \\
\hline 1 & $7,001 \leq \% \leq 10,000$ & Sangat layak \\
\hline 2 & $4,001 \leq \% \leq 7,000$ & Cukup layak \\
\hline 3 & $0,000 \leq \% \leq 4,000$ & Tidak layak \\
\hline
\end{tabular}

(Setiawan, 2019b: 227)

Tabel 2. Penafsiran Penilaian Keandalan Instrumen

\begin{tabular}{lcl}
\hline No. & Nilai Alfa Cronbach & Kategori Keandalan \\
\hline 1 & $\alpha \leq 0,9$ & Luar biasa \\
\hline 2 & $0,8 \leq \alpha<0,9$ & Baik \\
\hline 3 & $0,7 \leq \alpha<0,8$ & Dapat diterima \\
\hline 4 & $0,6 \leq \alpha<0,7$ & Dipertanyakan \\
\hline 5 & $0,5 \leq \alpha<0,6$ & Rendah \\
\hline 6 & $\alpha<0,5$ & Tidak dapat diterima \\
\hline
\end{tabular}

(disusun berdasarkan uraian Morera \& Stokes, 2016)

\section{HASIL DAN PEMBAHASAN}

Instrumen riset yang dirancang berjumlah 10 butir soal dengan indikator mengacu kepada domain kompetensi literasi saintifik dari kerangka kerja PISA seperti ditunjukkan melalui tabel 3. Indikator tersebut digunakan sebagai acuan dalam menyusun soal dengan konten terkait topik ekologi. Pilihan mengaitkan dengan topik tertentu dilakukan karena kami berupaya agar pembelajaran aktual di sekolah dapat diarahkan untuk melatih literasi saintifik. Sehingga diperlukan soal sebagai alat ukur literasi saintifik dari beragam topik, antara lain ekologi.

Soal disusun dalam bentuk uraian. Pilihan ini diambil karena soal tipe uraian unggul dalam mengukur kemampuan mengorganisasikan, mengintregasikan, menganalisis, menyintesiskan, dan mengevaluasi informasi (Fraenkel \& Wallen, 2009: 133-4). Sehingga bentuk uraian dipandang lebih cocok untuk digunakan. Bentuk ini juga dipilih untuk memperkecil peluang spekulasi siswa ketika menjawab pertanyaan yang disajikan. Banyak soal yang disusun ialah 3 kelompok untuk setiap topik. Kami menyadari bahwa untuk soal tipe ini, terdapat kesulitan dalam hal melakukan penyekoran. Sehingga kami membuat rancangan sederhana guna mengklasifikasikan skor dari setiap jawaban, yang ditampilkan melalui tabel 4.

yang kemudian dijumlah secara keseluruhan menggunakan persamaan berikut:

$$
N=\sum S
$$

keterangan:

$N \quad=$ skor setiap siswa

$S \quad=$ jawaban setiap butir soal

Setelah dilakukan validasi kepada 4 pakar, diperoleh penilaian yang beragam. Namun, secara umum soal sudah sesuai tanpa perlu banyak perubahan. Berdasarkan keseluruhan komentar tersebut, dilakukan klasifikasi setiap soal yang ditampilkan melalui tabel 5 .

Setelah melakukan perbaikan berdasarkan komentar keempat pakar, kami melakukan ujicoba soal. Hasil uji coba dijadikan sebagai acuan untuk menemukan nilai koefisien keandalan soal. Melalui uji coba juga bisa didapatkan informasi banyak waktu yang diperlukan siswa untuk menjawab soal. Setelah dilakukan uji coba soal, diperoleh hasil bahwa nilai konsistensi internal sebesar 0.763 , yang berarti instrumen penilaian dapat digunakan. Banyak waktu yang diperlukan siswa untuk menjawab soal ialah 45 menit.

Hasil riset ini diharapkan memberi bahan untuk memperoleh profil literasi saintifik siswa sebelum dan/atau setelah pembelajaran. Melalui profil sebelum 
pembelajaran, dapat disusun rancangan pembelajaran berorientasi literasi saintifik yang selaras dengan keadaan siswa. Sementara profil setelah pembelajaran dapat dipakai sebagai bahan evaluasi, baik dari sisi pelaksanaan proses, pencapaian hasil, keefektifan kegiatan, maupun ketiganya. Hasil riset ini juga dapat menjadi bahan kajian untuk diperbaiki secara berlanjut supaya lebih operasional ketika diterapkan di lapangan serta kuat dari sisi riset.

Tabel 3. Indikator Kompetensi Literasi Saintifik

\begin{tabular}{|c|c|}
\hline Kompetensi & Indikator \\
\hline \multirow{3}{*}{$\begin{array}{l}\text { Menjelaskan } \\
\text { secara ilmiah }\end{array}$} & Mengingat dan menerapkan pengetahuan ilmiah yang sesuai. \\
\hline & $\begin{array}{l}\text { Mengidentifikasi, menggunakan, serta menghasilkan model dan } \\
\text { representasi yang jelas. }\end{array}$ \\
\hline & $\begin{array}{l}\text { Menjelaskan implikasi potensial dari pengetahuan ilmiah bagi } \\
\text { masyarakat. }\end{array}$ \\
\hline \multirow{3}{*}{$\begin{array}{l}\text { Merancang } \\
\text { mengevaluasi } \\
\text { penyelidikan ilmiah }\end{array}$} & $\begin{array}{l}\text { Mengusulkan cara mengeksplorasi secara ilmiah terhadap } \\
\text { pertanyaan yang diberikan. }\end{array}$ \\
\hline & $\begin{array}{l}\text { Mengevaluasi cara mengeksplorasi secara ilmiah pertanyaan yang } \\
\text { diberikan. }\end{array}$ \\
\hline & $\begin{array}{l}\text { Mendeskripsikan dan mengevaluasi berbagai cara yang digunakan } \\
\text { oleh ilmuan untuk menentukan keabsahan dan keobjektifan data } \\
\text { serta keumuman penjelasan. }\end{array}$ \\
\hline \multirow{2}{*}{$\begin{array}{l}\text { Menafsirkan data dan } \\
\text { bukti secara ilmiah }\end{array}$} & Mengubah data dari satu representasi ke representasi yang lain. \\
\hline & $\begin{array}{l}\text { Menganalisis dan menafsirkan data dan menarik kesimpulan yang } \\
\text { tepat. }\end{array}$ \\
\hline
\end{tabular}

(OECD, 2013: 15-16)

Tabel 4. Klasifikasi Skor Setiap Jawaban

\begin{tabular}{ll}
\hline Skor & Bentuk Jawaban \\
\hline 2 & Sama seperti yang diharapkan \\
\hline 2 & Hampir seperti yang diharapkan tanpa terdapat pernyataan yang salah \\
\hline 1 & Mengandung hal yang benar dan terdapat pula pernyataan yang salah \\
\hline 0 & Jawaban tidak berhubungan dengan pertanyaan yang diajukan \\
\hline 0 & Tidak menjawab \\
\hline
\end{tabular}

PENUTUP

\section{Kesimpulan}

Berdasarkan riset yang telah dilakukan, dapat dilihat bahwa keabsahan dan keandalan instrumen penilaian menunjukkan soal termasuk dalam kategori dapat digunakan. Dengan demikian, soal yang disusun dapat dijadikan sebagai alat ukur literasi saintifik siswa dalam pembelajaran ekologi di sekolah menengah. Secara rinci, hasil validasi pakar memberi kesimpulan bahwa terdapat 7 soal kategori 'sangat layak' dan 3 soal kategori 'cukup layak'. Sementara berdasarkan hasil ujicoba, diperoleh nilai konsistensi internal sebesar 0.763 , yang berarti soal dapat digunakan. Banyak waktu yang diperlukan siswa untuk menjawab soal ialah 45 menit.

\section{Saran}

Kami berharap agar dilakukan riset lain yang serupa dari beragam topik pembelajaran. Harapan ini didasari fakta lapangan yang menunjukkan bahwa guru kerap kesulitan menyusun instrumen penilaian pembelajaran berorientasi literasi saintifik. Dengan keberadaan instrumen penilaian beragam topik, guru dan/atau peneliti dapat melakukan pengukuran literasi saintifik secara 
berlanjut, seperti menggunakan desain time series, tidak hanya mengukur dari satu topik saja, misalnya menggunakan desain one shot case study, untuk memperoleh keabsahaan dan keandalan hasil yang lebih tinggi. Selain itu, keragaman topik juga lebih memudahkan guru untuk menunjukkan kepada siswa kaitan antara pengalaman terlibat pembelajaran dengan keterampilan yang ditargetkan dapat dimiliki

Tabel 5. Hasil Validasi Pakar

\begin{tabular}{lllllll}
\hline \multirow{2}{*}{ Nomor Soal } & \multicolumn{3}{l}{ Skor dari Pakar } & \multirow{2}{*}{ Jumlah Skor } & \multirow{2}{*}{ Kriteria Soal } \\
\cline { 2 - 5 } & $\mathbf{1}$ & $\mathbf{2}$ & $\mathbf{3}$ & $\mathbf{4}$ & & Cukup Layak \\
\hline 1 & 7 & 2 & 5 & 3 & 61 & Sangat Layak \\
\hline 2 & 3 & 6 & 6 & 6 & 75 & Cukup Layak \\
\hline 3 & 3 & 5 & 5 & 5 & 64 & Sangat Layak \\
\hline 4 & 7 & 5 & 6 & 5 & 82 & Cukup Layak \\
\hline 5 & 6 & 4 & 6 & 3 & 68 & Sangat Layak \\
\hline 6 & 5 & 6 & 5 & 6 & 79 & Sangat Layak \\
\hline 7 & 7 & 4 & 6 & 6 & 82 & Sangat Layak \\
\hline 9 & 7 & 3 & 4 & 6 & 71 & Sangat Layak \\
\hline 10 & 7 & 6 & 7 & 6 & 93 & Sangat Layak \\
\hline
\end{tabular}

\section{UCAPAN TERIMA KASIH}

Adib Rifqi Setiawan mengucapkan terima kasih kepada warga Madrasah Tasywiquth Thullab Salafiyyah (TBS) Kudus yang memberi dukungan pembelajaran aktual; serta Dr. Setiya Utari dari Sekolah Pascasarjana Universitas Pendidikan Indonesia (SPs UPI) Bandung dan Syarofis Si'ayah, S.Kes. yang memberi dorongan psikis dan bantuan teknis.

\section{REFERENSI}

Dawes, John. 2008, 01 Januari. Do data characteristics change according to the number of scale points used? an experiment using 5-point, 7-point and 10-point scales. International Journal of Market Research, 50 (1): 61-77. DOI:

https://dx.doi.org/10.1177\%2F14707 8530805000106

Fraenkel, Jack R. \& Wallen, Norman E. 2009. How to design and evaluate research in education (7th ed.). New York. McGraw-Hill Companies. URL: https://archive.org/details/methodolo gy-alobatnic-libraries

Hurd, Paul deHart. 1998. Scientific literacy: New minds for a changing world. Science education, 82(3), 407416.

DOI: https://dx.doi.org/10.1002/(SICI)109 8-237X(199806)82:3\%3C407::AIDSCE6\%3E3.0.CO;2-G

IBO. 2019, 15 Juli. International biology olympiad: indonesia. ibo-info.org. URL: http://www.iboinfo.org/countries/indonesia

IChO. 2019, 15 Juli. International chemistry olympiad: indonesia. ichoofficial.org. URL: http://www.ichoofficial.org/results/country_info.php? country=Indonesia

IESO. 2019, 15 Juli. List of medal and team award winners. ieso-info.org. URL: http://www.iesoinfo.org/documents/honor-board/

IOAA. 2019, 15 Juli. Participating countries. ioaastrophysics.org. URL: http://www.ioaastrophysics.org/parti cipating-countries/ 
IPhO. 2019, 15 Juli. International physics olympiad: indonesia. iphounofficial.org. URL: https://iphounofficial.org/countries/IDN/individ ual

Likert, Rensis. 1932. A technique for the measurement of attitudes. Archives of Psychology, 140 : 1-55. URL: https://legacy.voteview.com/pdf/Like rt_1932.pdf

Morera, Osvaldo F.; \& Stokes, Sonya M. 2016, Maret. coefficient $\alpha$ as a measure of test score reliability: review of 3 popular misconceptions. American Journal of Public Health, 106(3): 458-461. DOI: https://dx.doi.org/10.2105\%2FAJPH. 2015.302993

OECD. 2018, 25 September. Pisa for development science framework. Dalam PISA for Development Assessment and Analytical Framework: Reading, Mathematics and Science. Paris: OECD Publishing.

DOI: https://dx.doi.org/10.1787/97892643 05274-6-en

OECD. 2019, 01 Juni. Science performance (pisa) (indicator). DOI: https://dx.doi.org/10.1787/91952204en

Rustaman, Nuryani Y. 2017, 29 April. Mewujudkan sistem pembelajaran sains/biologi berorientasi pengembangan literasi peserta didik. Prosiding Seminar Nasional III
Tahun 2017 "Biologi, Pembelajaran, dan Lingkungan Hidup Perspektif Interdisipliner", p. KS. URL: http://research-

report.umm.ac.id/index.php/researchreport/article/viewFile/944/1157

Setiawan, Adib Rifqi. 2019a, 07 Mei. Penerapan pendekatan saintifik untuk melatih literasi saintifik dalam domain kompetensi pada topik gerak lurus di sekolah menengah pertama. Prosiding Seminar Nasional Fisika (SiNaFi) 2018, 4 (1): 7-13. URL: http://proceedings.upi.edu/index.php/ sinafi/article/view/355

Setiawan, Adib Rifqi. 2019b, 26 Juni. Peningkatan literasi saintifik melalui pembelajaran biologi menggunakan pendekatan saintifik. Journal of Biology Education, 2 (1): 223-235. DOI: 10.21043/jobe.v2i1.5278

Setiawan, Adib Rifqi; \& Sari, Dewi Ratna. 2019, 16 April. A simple essay of natural science curricula in indonesia. Open Science Framework. DOI: https://doi.org/10.31219/osf.io/uwn4r Utari, Setiya, dkk. 2017, Februari. Recostructing the physics teaching didactic based on marzano's learning dimension on training the scientific literacies. Journal of Physics: Conference Series, 812 (1): 012102. DOI:

https://dx.doi.org/10.1088/17426596/812/1/012102 


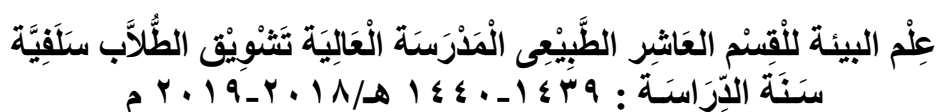

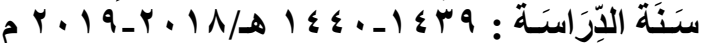

Nama lengkap : Kelas : $\mathrm{X}(\mathrm{A} / \mathrm{B} / \mathrm{C})$

Nomor urut : Tanggal: $\_ـ$

\title{
Jawablah pertanyaan berikut dengan jelas disertai alasan pendukung!
}

\begin{abstract}
Jisoo dan Jennie belajar ragam interaksi antar komponen ekosistem. Tak puas dengan pembelajaran di kelas, keduanya berinisiatif untuk melakukan percobaan bersama berupa menanam kunyit di halaman rumah yang sama. Bedanya ialah Jisoo hanya menanam kunyit saja, sedangkan Jennie menanam kunyit dan petai cina secara bersilangan. Guna menguatkan pembahasan yang akan dilakukan, Jisoo dan Jennie membaca artikel riset terkait interaksi antara kunyit, petai cina, dan tumbuhan lain. Dari bacaan diperoleh informasi bahwa petai cina dapat mengurangi hasil kunyit dan gandum, tapi meningkatkan hasil jagung dan beras. Sementara data hasil percobaan selama satu bulan menunjukkan bahwa kunyit yang ditanam Jisoo lebih mudah tumbuh daripada tanaman Jennie.
\end{abstract}

1) Apa saja manfaat percobaan yang dilakukan oleh Jisoo dan Jennie?

2) Apakah gambaran percobaan tersebut sudah sesuai dengan tujuan riset?

3) Bagaimana kaitan antara data percobaan dengan penjelasan pustaka?

\section{Aliran Energi Daur Biogeokimia}

Peran penting nitrogen $\left(N_{2}\right)$ dalam proses kehidupan ialah sebagai pembentuk protein yang merupakan komponen penyusun asam nukleat (DNA dan RNA). Namun, sebagian besar tumbuhan dan hewan tidak dapat memanfaatkan nitrogen bebas di udara. Tumbuhan menyerap nitrogen dalam bentuk nitrat $\left(\mathrm{NO}_{3}^{-}\right)$menggunakan akarnya. Sementara hewan memperoleh nitrogen dari protein nabati yang dihasilkan oleh tumbuhan. Ketika tumbuhan dan hewan sudah mati, kandungan nitrogen keduanya diurai menjadi amonia $\left(\mathrm{NH}_{3}\right)$ oleh Bacillus subtilis. Amonia lalu diubah menjadi nitrit $\left(\mathrm{NO}_{2}^{-}\right)$oleh Nitrosomonas, yang hasilnya dipakai oleh Nitrobacter untuk menghasilkan nitrat.

4) Bagaimana tabel kaitan antara organisme serta unsur yang dibutuhkan dan dihasilkan?

5) Bagaimana skema daur biogeokimia yang menunjukkan bahwa kelima organisme tersebut saling berhubungan?

6) Apa saja variabel (bebas dan terikat) terkait reaksi yang dialami Nitrobacter?

\section{Penanganan Perubahan Lingkungan}

Ketika memimpin proyek pembangunan sirkuit MotoGP dari DORNA di Kabupaten Kudus pada 2019 yang harus siap pakai pada 2024, Rosé ingin agar hasilnya ramah lingkungan. Karena itu dirinya mengumpulkan data sebagai berikut:

a) Jumlah kendaraan untuk setiap sesi balapan paling banyak ialah 30 sepeda motor;

b) Bahan bakar setiap kendaraan ialah Pertamax Plus;

c) Setiap kendaraan membutuhkan 1 liter setiap mengelilingi sirkuit sepanjang $5 \mathrm{~km}$;

d) Daftar pohon yang dapat dipilih Rosé untuk ditanam di lingkungan sirkuit sebagai berikut: 


\begin{tabular}{cllc}
\hline $\begin{array}{c}\text { No } \\
\cdot\end{array}$ & Pohon & \multicolumn{1}{c}{ Nama Ilmiah } & $\begin{array}{c}\text { Daya Serap CO2 } \\
\text { (g/jam.pohon) }\end{array}$ \\
\hline 1 & Mahoni & $\begin{array}{l}\text { Swietenia } \\
\text { macrophylla }\end{array}$ & $3.112,43$ \\
\hline 2 & $\begin{array}{l}\text { Palem } \\
\text { Phoenix }\end{array}$ & Phoenix roebelenii & 0,39 \\
\hline 3 & Kersen & Muntingia calabura & 0,6 \\
\hline 4 & Beringin & Ficus benjamina & $1.146,51$ \\
\hline 5 & Trembesi & Samanea saman & $3.252,10$ \\
\hline
\end{tabular}

7) Apa saja faktor yang perlu diperhatikan Rosé ketika merencanakan pembangunan agar hasilnya sesuai keinginan tersebut?

8) Apa kemungkinan yang dapat terjadi terhadap udara ketika balapan berlangsung?

9) Bagaimana langkah perencanaan yang dapat dilakukan Rosé agar sirkuit yang dibangun ramah lingkungan?

10) Apa makna data yang diperoleh Rosé terkait langkah perencanaan yang dilakukan?

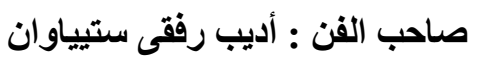

